\title{
REGIONAL PLANNING AUTHORITY IN MALAYSIA: LEGAL AND INSTITUTIONAL FRAMEWORK*
}

\author{
Ainul Jaria Maidin and \\ Sharifah Zubaidah Syed Abdul Kader**
}

\begin{abstract}
The idea that local authorities should be the ones determining the affairs of their local authority areas is an engrained rule in the structure of the Malaysian style of government. Of late, regional planning has gained prominence with the realization that it promotes effective and efficient use of resources and reduces regional imbalances and poverty as well as may help in achieving sustainable development. Malaysia has the legal framework for establishing a regional planning authority that crosses the boundaries of two or more states, yet none has been set up to date. This paper analyses the related provision, examines the proposed institutional framework and identifies the challenges that the government may face in establishing a regional planning authority, including political will, state
\end{abstract}

\footnotetext{
* Updated version and fusion of papers presented at the New Zealand Planners Institute Conference 2007 “The Politics of Planning," 27-30 March 2007, at Palmerston North, New Zealand.

Assistant Professors, Ahmad Ibrahim Kulliyyah of Laws, International Islamic University Malaysia.
} 
autonomy in a federal system of government, and the scope and powers of such authority. A comparison of the setting up of regional authorities in Australia and Canada is also included, being countries applying the federal system of government like Malaysia.

\section{INTRODUCTION}

The idea that local authorities should be the ones determining the affairs of their local authority areas is an engrained rule in the structure of the Malaysian style of government. Historically, local government has been responsible in shaping the development of urban and rural land use, transportation plans and various other land development issues within the boundary of its local authority areas. However, recent innovative concepts such as "smart growth," "new regionalism," "new urbanism" or "metropolitan regional planning" have been gaining prominence amongst planners and appears to be challenging the decision making powers of the local authorities. It is nothing to be alarmed about since the problems of growth and development in urban and rural regions of the state transcend the boundary lines of local government units that no single unit can plan for their solution without affecting other units in the region. As such coordination of multi jurisdictional activities is essential to the development and implementation of effective policies and programmes, be it for improving social and economic development, or environmentally sustainable land development activities.

By its iterative and integrated nature, regional planning looks at the needs of those who share the system in question; it understands the limits of the resources available to solve those needs; and it reflects broad agreement over the use of those resources. Thus, in short, regional planning looks towards cooperation and coordination, it is integrated and integrative, it is developmental, and, within that category, it is conservationist.

The amendment to the Town and Country Planning Act 1976 ('the Act') in 2001 introduced Part IIA comprising of section 6A to the Act which empowers the National Physical Planning Council to establish a Regional Planning Committee for purposes of coordinating development involving several local authority areas. However, the analysis of this 
provision clearly demonstrates that the regional planning committee is not given any powers to enforce laws within a region.

Furthermore, whenever a development plan for a region is announced, almost always the 'powers that be' will promote such plan in the hope of attracting private sector investment. Notwithstanding the fact that a regional plan is considered as a tool of governance, ${ }^{1}$ its full utilization as such, is questionable. It is given much hype in the media by the government of the day and its fate subsequently falls on bodies and agencies that later on find it quite difficult to implement. Planners will begin justifying the slow progress of the plans' implementation to a host of factors including the development of new assumptions, new realities, and new challenges. It is accepted that the conformity of land use development to any planning document is a constantly moving target. ${ }^{2}$ Other than keeping an eye on this 'moving target,' there is a need to consistently look at the changing 'rules of the game' and to make correct decisions on 'how to play it right.' This article raises questions on the setting up an institutional framework for regional planning from a legal perspective by looking at the legal provision, the system of government as well as the planning system applied in such government system. This, it is contended, would be a good starting point for discussing a regional planning set-up that would necessarily cross-administrative and political boundaries.

Through analysis of section 6A of the Town and Country Planning Act 1976 and its legal and political background, this article examines the strength and weaknesses of the legal and institutional framework providing for establishment of the Regional Planning Committee in promoting effective regional growth and sustainable development in the regions in Malaysia as envisaged by the National Physical Plan.

\footnotetext{
$1 \quad$ Olsson, “Governance and planning for a new age” in Snickars, Olerup \& Persson (Eds.) Reshaping Regional Planning: A Northern Perspective (pp. 95-117), Ashgate (2002).

2 Kamalruddin Shamsuddin, "Sustainable Land Use Development in the Klang Valley: An Elusive Dream” in Hunud Abia Kadouf, Sharifah Zubaidah (Eds.) Land Use Planning and Environmental Sustainability in Malaysia: Policies and Trends (pp. 297-314). Research Centre, International Islamic University Malaysia (2006).
} 


\section{MALAYSIA'S LOCAL GOVERNMENT SYSTEM}

The effectiveness of any legal and institutional set up proposed under the planning system must be considered against the backdrop of the local government system in Malaysia. Malaysia is a federation of states that practices parliamentary democracy. It has a Federal Constitution as the supreme law of the land, and a constitutional monarchy. There are three levels of government, at the top of the hierarchy being the federal government, after that, the state government and finally, the local government. Local government is put under the State List under the Federal Constitution, and it is the state authority that appoints local councillors. ${ }^{3}$ The Federal government exerts control over local government matters through the National Council for Local Government, a federal level council established under the Federal Constitution. This council is a consultative council to formulate from time to time, policies on the promotion, development and control of local government throughout Malaysia and the administration of laws relating to local government. Although the federal and state governments are expected to follow the policies, there have been cases of departure as there is a lack of censuring power.

There have been no local elections in Malaysia since 1963 and this is largely due to historical factors. Malaysia's Local Government Act, 1976 today provides in section 15 that 'all provisions relating to local government elections shall cease to have force or effect.' The view is that the government of the day is not in favour of local government elections (possibly largely due to socio-political factors) and prefers the system of appointed councillors. The reason for departing from the system of electing councillors lies in national security as well as the achievement of the aims of Malaysia's New Economic Policy, namely, 'the restructuring of society.'

In Malaysia's federal system, the local government is not autonomous and is empowered to act only in accordance with the existing written laws applicable to it, namely the Local Government Act, 1976,

\footnotetext{
$3 \quad$ Section 10, Local Government Act, 1976 (Act 171).

$4 \quad$ See Sharifah Zubaidah Syed Abdul Kader, Legal Control of Commercial Land Development in Kuala Lumpur and Petaling Jaya, unpublished SJD dissertation submitted to Bond University, Australia. pp.115-116, (2002).
} 
the Town and Country Planning Act, 1976 and the Street, Drainage and Building Act, 1974.

In the day to day administration, the federal government deals with local governments primarily through the Ministry of Housing and Local Government. Such dealings are carried out through the state government, in particular the State Local Government Division. Federal fiscal transfers include the provision and launching of annual grants, minor projects grants and the contribution in-lieu-of-rate that are made through this relationship. Beyond that, the federal government cannot interfere directly in the affairs of local authorities. The federal government is helpless even in reported cases where the state withholds, albeit temporarily, the Federal contribution in-lieu of rates for local authorities or the state refusal to impose new rates based on the property revaluation done by the Ministry of Finance. In essence, for implementation purposes, financial initiatives greatly depend on the state government. The State Authority has direct financial powers over local authorities. Such powers are also incorporated in the Local Government Act, 1976. ${ }^{5}$

\section{MALAYSIA'S TOWN PLANNING SYSTEM}

Malaysia's town planning system emanated from the English development plan system. The development plans under Malaysia's Town and Country Planning Act, 1976 consists of a Structure Plan prepared at state level and local plans prepared at local levels. Although the planning statute has been amended a few times to make the planning system more consultative in nature, any proposed institutional framework must still work within a top-down approach in the planning hierarchy. See Figure 1 below: 


\section{Figure 1: Planning Hierarchy in Malaysia}

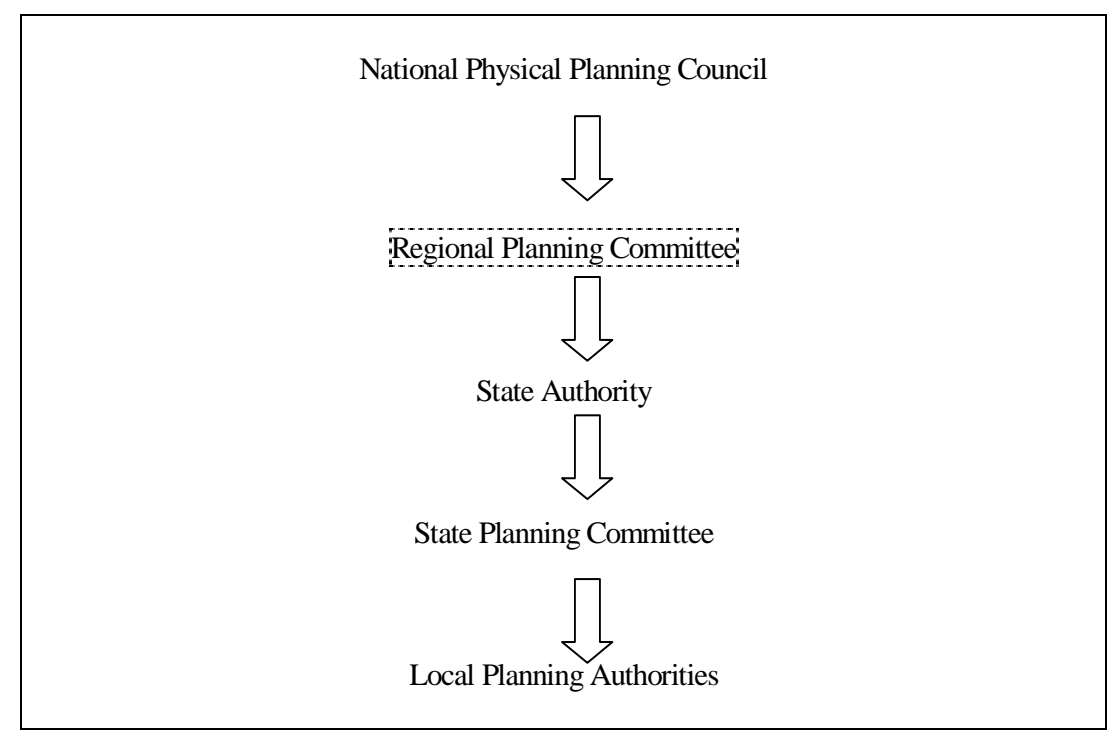

At the top of this planning hierarchy is the National Physical Planning Council, an advisory council at federal level chaired by the Prime Minister. This Council consists of representatives from various federal ministries responsible for managing sustainable land development and related matters. ${ }^{6}$ This was a political arrangement that allows for the sharing of departmental responsibilities between a number of ministries such as the Ministry of Housing and Local Government, Ministry of Natural Resources and the Environment, Ministry of Public Works, and a few others to form a forum at the federal level to enable the federal and state governments to coordinate affairs affecting land use planning and development control in the country.

The National Physical Planning Council must be consulted by the State Authorities prior to embarking on any of the following land development activities: ${ }^{7}$

\footnotetext{
$6 \quad$ Town and Country Planning Act 1976, s. 2A(1).

$7 \quad$ Town and Country Planning Act 1976, s. 22 (2A)(a)(b) and (c).
} 
(a) the development of a new township for a population exceeding ten thousand, or covering an area of more than one thousand hectares, or both;

(b) a development for the construction of any major infrastructure or utility;

(c) a development affecting hill tops or hill slopes, in an area designated as environmentally sensitive in a development plan.

The functions of the National Physical Planning Council, amongst others, is to ensure that the town and country planning process will be an effective and efficient instrument for the improvement of the physical environment which will in turn be able to promote the achievement of sustainable development in the country. ${ }^{8}$ However, the Council must ensure that this process does not conflict with national policies. The National Physical Planning Council is required to advise the federal government or the government of any state, on matters relating to town and country planning as prescribed in the Town and Country Planning Act 1976 in order to promote sustainable development as well as uniformity of laws and procedure.

Given the fact that under the Federal Constitution, land is a state matter, and town planning is a concurrent matter between the federal government and the state government, town planning in Malaysia is still very much a state stronghold notwithstanding the presence of this federal level council. Thus, each state has a State Planning Committee to advise the State Authority on matters relating to regulating and coordinating all development activities in the state. Under the State Planning Committee are the various local planning authorities for each local authority area in the State. sustainably was outlined in the $2^{\text {nd }}$ Outline Perspective Plan and all of the government's five year development plans. 


\section{MOVE TO PROMOTE REGIONAL PLANNING IN MALAYSIA}

Efforts at regional planning in Malaysia had begun with the setting up of regional development authorities such as KEJORA, KESEDAR, KETENGAH, KEDA, DARA, JENGKA, PERDA. These were all established by Acts of Parliament and accepted for application in the state through state enactments. The model of regional development authorities that existed in Kedah, Pahang and Johor above, may not be suitable for implementation in a region that crosses administrative boundaries of two states as their administrative boundaries are within one state only. Furthermore their purposes were for resource-frontier development and agricultural development and not totally physical planning.

The need to establish a regional planning authority in Malaysia was first discussed for the Klang Valley region, located in the most active development area of the country. The First Klang Valley Study was undertaken by Shankland \& Cox Partnership in December 1972 covering an area of about 1,220 square miles and a population base of 1.268 million. It provided the first opportunity to relate the social objectives of the Malaysian Government's New Economic Policy to the planning and development of a major urban region in the country. The Plan showed how regional growth might be guided to make the maximum contribution to the reduction of poverty and the restructuring of society and including all of the following:

- $\quad$ accommodate the natural growth of the region's population in balanced urban communities;

- $\quad$ reduce unemployment;

- $\quad$ absorb rural migrants into productive urban activities;

- development; and creating an effective process of continuing planning activities capable of both directing and responding to social and economic change;

- $\quad$ create opportunities for Malay ownership and control of industrial and commercial activities;

- $\quad$ create new forms of racial co-operation in both established and new urban centres;

- $\quad$ provide better transport facilities, especially public transport, while reducing congestion in Kuala Lumpur; 
- $\quad$ improve and extend public services; especially in drainage and sewerage;

- $\quad$ promoting greater collaboration between all State and Federal agencies in guiding and implementing plans.

The Klang Valley Regional Planning Unit was established to prepare the Klang Valley Region Perspective Plan to guide the growth within the Klang Valley region. The Unit was expected to focus on integrated decision making. However, no strong institutional nor legal framework for the Klang Valley region existed. This dampened the process considerably despite having produced two regional plans since its inception.

During the Eighth Malaysia Plan period, efforts were made to promote balanced regional development because there were development gaps between regions, states and rural and urban areas. ${ }^{9}$ During the Ninth Malaysia Plan period, measures are to be undertaken to accelerate the development of less developed states particularly in the Northern Peninsular Malaysia and the Eastern Corridor to attain regional balance and reduce developmental gaps.

The Federal Government of Malaysia, sensing similar problems in various other regions decided to provide a legal framework for the establishment of a regional planning authority for various regions throughout the country. The Federal Town and Country Planning Department was advised to study the possibilities of establishing regional planning authorities to promote regional development and reduce regional imbalances. Thus, this culminated in the insertion of section 6A to the Town and Country Planning Act 1976 that can be considered as an important development in promoting regional development in Malaysia. ${ }^{10}$ The provision provides that the National Physical Planning Council ${ }^{11}$ at the Federal Government level, can establish a joint board known as the 'regional planning committee' as the planning authority for the areas or

\footnotetext{
$9 \quad$ Prime Minister’s Department 2006, pp. 355-371.

10 This Part and section were inserted by the Town and Country Planning (Amendment) Act 2001 (Act A1129), s. 11.

11 Provision for establishment of the National Physical Council was introduced with the insertion of section 2A to the Town and Country Planning (Amendment) Act 2001 (Act A1129), s. 7.

12 Town and Country Planning Act 2976, s. 6A(1).
} 
region of any two or more States as and when the need arises in order to manage the affairs of a region situated within two or more states. ${ }^{12}$ The establishment of a regional planning committee is expedient to provide cohesion in the administration of planning functions over a wider area and jurisdiction than that administered by a local planning authority. ${ }^{13}$ This is deemed important since the National Physical Planning Council is entrusted to ensure that the development within the country is sustainable in all aspects including economic, social and environment.

A new development with regard to regional planning in Malaysia is the development of 'growth corridors' in Peninsular Malaysia, primarily to attract foreign investment. The first to be introduced, and which is presently in the process of being implemented, is the South Johor Economic Region (SJER) now termed as the Iskandar Development Region ('IDR'). The legal and institutional set-up for IDR is governed by a special statute, namely, the Iskandar Development Region Authority Act (Act 664). This region is a special economic zone located in the state of Johor encompassing an area of 2,217 square kilometers. IDR's model may not be suitable for a region that crosses the administrative boundaries of two or more states as the region is within one state only. Nevertheless, it's development would be interesting to observe, especially from the aspect of coordinating the various local planning authorities. IDR aims to be a sustainable region of international standard. The beacon of new growth, IDR will spur economic developments that actuate Malaysia's global potential. Recognising the need for sustainable development, social and environmental issues features heavily on its agenda. IDR's commitment to these causes are evident in its manifestation within the IDR Masterplan. ${ }^{14}$

\footnotetext{
$13 \quad$ Town and Country Planning Act 2976, s. 6A(1).

14 Iskandar Region Development Authority, Accessed via Internet at http://www.idr.com.my/ on 20 December 2007.

15 The Northern Corridor Economic Region development programme is a Government initiative to accelerate economic growth and elevate income levels in the north of Peninsular Malaysia-encompassing the states of Perlis, Kedah, Pulau Pinang and the north of Perak. Northern Corridor Economic Region (NCER) (Malay: Wilayah Ekonomi Koridor Utara) is a new economic development corridor in Malaysia. NCER is also one of the three development regions formed in Peninsular Malaysia. The NCER initiative will span from 2007 to the end of the 12th Malaysia Plan Period, i.e. 2025. The NCER was launched on 30 July 2007 in Alor
} 
Other growth corridors developing in Malaysia are the Northern Corridor Economic Region (NCER), ${ }^{15}$ the East Coast Economic Region (ECER) development ${ }^{16}$ and the Sabah Development Corridor. Similar to the Iskandar Development Region Authority, both the NCER and ECER will have implementation authorities in the form of a body corporate that are given functions and powers under a special statute. ${ }^{17}$ Under their

Star, Kedah and on 31 July 2007 in Butterworth, Penang. Both events were launched by its own Chairman which is the Malaysian Prime Minister Datuk Seri Abdullah Ahmad Badawi. The key thrusts are to transform and expand the agricultural, manufacturing, tourism and logistics sectors in the region. Accessed via Internet at http:// www.ncer.com.my/

16 East Coast Economic Region (ECER) (Malay: Wilayah Ekonomi Pantai Timur) is a new economic development corridor in Malaysia. This programme is a Government initiative to accelerate economic growth and elevate income levels in the east coast of Peninsular Malaysia which covers states of Kelantan, Terengganu, Pahang and the north of Mersing district of Johor. The ECER was launched by Malaysia's Prime Minister, Abdullah Ahmad Badawi in Kuala Terengganu and Kota Bahru on October 30, 2007 and in Kuantan the next day. During the launch of the project, the Prime Minister announced a RM6 billion allocation for the opening phase of the project, strengthening the Malaysian government's commitment to the project. ECER development roadmap was based on a master plan involving 227 projects in the agriculture, education, infrastructure, manufacturing, oil and gas, transportation and tourism industries. The eastern corridor development blueprint, which is expected to be out this quarter at the earliest, is said to be focused on the socio-economic and industrial development of the region involving Kelantan, Terengganu and Pahang. The development of the eastern corridor, together with the northern corridor spearheaded by Sime Darby Bhd and southern corridor (Khazanah Nasional Bhd) are part of the Ninth Malaysia Plan (9MP), which has the objective of spreading economic development throughout the country. Aseambankers Malaysia Bhd said the eastern corridor offers big potential for certain industries, especially oil and gas $(O \& G)$ and tourism. Accessed via Internet at http:// biz.thestar.com.my/news/story.asp?file=/2007/4/30/business/ $17536506 \&$ sec $=$ business.

17 See Northern Corridor Implementation Authority Act 2008 (Act 687) and the East Coast Economic Region Development Council Act 2008 (Act 688). 
special statutes, both authorities are empowered to prepare comprehensive development plans for the region and in preparing those plans are to secure that these plans are in line with the National Physical Plan and that the proposals generally conform with the state Structure Plans. ${ }^{18}$

As the development of these growth corridors are still at their infancy stages, it would be interesting to further observe how the legal and institutional set up of the authorities established for these corridors will fit into the national planning system in Malaysia. As it is, we do not yet see any move towards applying the 'regional planning committee' concept under section 6A of the Town and Country Planning Act 1976 in these new growth corridors.

\section{REGIONAL PLANNING UNDER THE NATIONAL PHYSICAL PLAN}

The National Physical Planning Council formulated the National Physical Plan ('NPP'). The NPP is a long-term strategic plan for the period until 2020, that contains written statements formulating strategic policies for the purpose of determining the general directions and trends of the physical development and conservation of Peninsular Malaysia, accompanied by indicative plans. NPP has been prepared under the provision of Section 6B of the Town and Country Planning Act 1976. The NPP has been approved by the Cabinet on 20th April 2005 and by the National Physical Planning Council (NPPC), chaired by the Prime Minister, on 26th April 2005. ${ }^{19}$

Section 6B (5) of the Town and Country Planning Act 1976 provides that, "It shall be the general duty of the Federal Government and the Government of every State to assist in ensuring that the objectives of the national physical plan are achieved." As such all state governments are expected to help to realise the objectives outlined in the NPP. The goal of the National Physical Plan is to create an efficient, equitable and

\footnotetext{
$18 \quad$ Ibid.

19 http://www.npptownplan.gov.my/index.php?module=ContentExpress \&func=display\& ceid=13>Accessed on 20 November 2006.
} 
sustainable national spatial framework to guide the overall development of the country towards achieving a competitive developed nation status by $2020 .^{20}$ The objectives of the Plan are as follows:
- $\quad$ to rationalise national spatial planning for economic efficiency and global competitiveness.
- $\quad$ to optimise utilisation of land and natural resources for sustainable development.
- $\quad$ to promote balanced regional development for national unity.
- $\quad$ to secure spatial and environmental quality and diversity for a high quality of life.

This is in line with the ideology of post independence Malaysian planning law which aims at regulating and securing the most efficient and effective use of land taking into account public interest, though not entirely at the expense of the individual, particularly in the wave of the increasing demand of the urban population. Most importantly is the underlying philosophy that land use planning must in the first place fulfil national integration which is an essential requirement for a plural society like Malaysia. This philosophy has been put into effective practice by not only taking the various regional and local land policies into account but also by integrating those policies to form an integral part of the general schema of the national land use planning system.

The National Physical Plan, besides addressing the issue of the country's need for global competitiveness, is also required to address the issue of regional imbalance. Regional balance is, therefore, interpreted as equal access to equitable levels of real income and personal development opportunities and not necessarily as equal opportunity to the same forms of development. Land and natural resources of the less developed regions, which still remain not fully utilised, should be further used to increase the productivity of these regions and, therefore, help to reduce regional imbalances. Resource-based industries, forestry-based activities and industries, downstream agriculture-based activities, resort tourism, in particular eco-tourism, craft-based industries and other niche activities -

$20 \quad$ Federal Department of Town and Country Planning Malaysia, National Physical Plan Malaysia, http://www.npptownplan.gov.my/ index.php? module $=$ ContentExpress \& func $=$ display $\&$ ceid $=14$ Accessed on 20 November 2006. 
in other words economic activities that are not subject to the same degree of global competition as the activities that are being attracted to the conurbations should be directed to the less developed regions.

The Plan provides the basis for the National Physical Planning Council to establish Regional Planning Committees for regions in Peninsular Malaysia for purposes of promoting a balanced regional development for national unity. Though a committee has yet to be established, the Plan has identified one national conurbation area comprising of Kuala Lumpur- Klang Valley, Seremban. ${ }^{21}$ The creation of three other conurbations has also been proposed. The first is the George Town, Kulim, Sungai Petani and North Perak conurbation, second is the Johor Bahru, Pasir Gudang and Tanjung Pelepas conurbation and the last is the Kuantan and Kemaman conurbation. Policy No.10 of the National Physical Plan provides that the growth of the four main conurbations of Kuala Lumpur, George Town, Johor Bahru and Kuantan shall be supported with the relevant infrastructure, and complete facilities to meet the needs of the manufacturing industry, ICT, tourism health and biotechnology.

$21 \quad$ An area within $45 \mathrm{~km}$ radius from workplace to town centre. 
Figure 2: Malaysian National Spatial Framework 2020

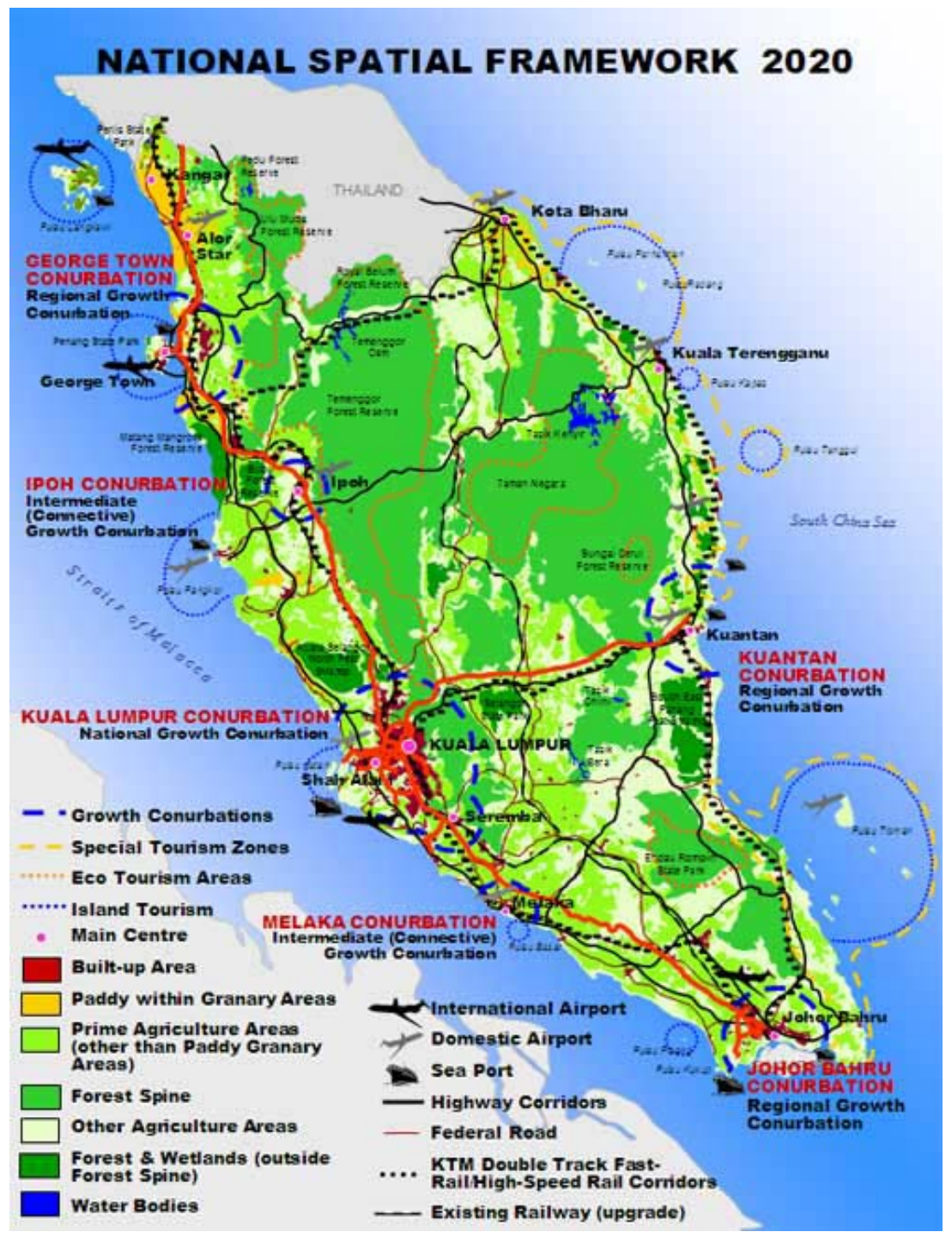

Source: Federal Town and Country Planning Department Malaysia 2005 


\section{LEGAL FRAMEWORK FOR ESTABLISHING A REGIONAL PLANNING AUTHORITY}

The National Physical Planning Council can establish a joint board known as the regional planning committee as the planning authority for the areas or region of any two or more States as and when the need arises in order to manage the affairs of a region situated within two or more states. ${ }^{22}$ The establishment of the committee can be made after consultation with the Federal and State authorities of the affected areas. The Act has failed to prescribe any particular mode of consultation. However consultation may often be a continuous process where the federal and state government may consult the committee as and when the need arises. The establishment of the regional planning committee is aimed at providing cohesion in the administration of planning functions over a wider area and jurisdiction than that administered by a local planning authority. The National Physical Planning Council has discretionary powers in establishing the regional planning committee after consultation with the federal and state governments involved.

The membership of the regional planning committee consists of, ${ }^{23}$ a Chairman, who is appointed by the Prime Minister; six persons representing the Federal Government, at least four of whom shall be public officers, appointed by the Minister; not more than four persons representing the Government of each of the States within the region, appointed by the State Authority, one of whom shall be the State Director; the President of every local planning authority within the region if such authority is a local authority. A Secretary for the regional planning committee will be appointed by the Director General of Town and Country Planning. ${ }^{24}$

The functions of the regional planning committee are as follows: ${ }^{25}$

- $\quad$ to advise and assist the State Planning Committees and the local planning authorities within the region pertaining to the development plans appropriate for the region, in accordance with the national policy; 
- $\quad$ to establish policies and to devise a comprehensive regional plan to guide and co-ordinate development of the region;

- $\quad$ to plan and co-ordinate the provision of infrastructure and facilities for the region;

- $\quad$ to establish uniform process and procedures to be used by the Federal Government and the State Governments and local authorities concerned for the region;

- $\quad$ to monitor the implementation of standards, guidelines and procedures in facilitating the development of the region; and - $\quad$ to conduct research required for the planning of the region.

The important keywords in the functioning of the proposed regional authority are 'plan,' 'guide' and 'coordinate.' It does not seem to be a regulator or implementor but merely a supervisory and advisory authority. No regional authority has yet to be set up under the said legal provision in Malaysia.

\section{CHALLENGES IN ESTABLISHING A REGIONAL PLANNING AUTHORITY}

There are various challenges for the government in establishing a regional planning authority in Malaysia that will be able to effectively manage the affairs of a particular region. The following are some of the pertinent issues needing serious attention:

\section{(a) Jurisdictional Conflict Between Authorities Involved in Executing Planning Functions}

At present there are three different authorities empowered at different strategic levels to manage and administer land use planning matters as provided by the Town and Country Planning Act 1976. ${ }^{26}$ These authorities are, the National Physical Planning Council at the Federal government level, the State Planning Committee at the state level and the Local Planning Authority at the local level. Subject to Clauses (5) 
and (6) of Article 91 of the Federal Constitution of Malaysia, the State Authority shall be responsible for the general policy in respect of the planning of the development and use of all lands and buildings within the area of every local authority in the State. ${ }^{27}$ This is principally due to the delineation in the Federal Constitution of the responsibilities and jurisdiction of the Federal and State governments accordingly by itemizing and classifying the matters into three different Lists. ${ }^{28}$ This is necessary to assure the sovereign Malay States that are used to administering their respective states affairs that their powers will not be usurped by the Federal Government. This is the essence of federalism that has been described as "the establishment of a single political system, within which, general and regional governments are assigned to coordinate authority such that neither level of government is legally or politically subordinate to the other." 29

Town and country planning is listed in the Concurrent List in the Federal Constitution, being the list enumerating the matters with respect to which both Parliament and a State Legislature may make laws. As such both the Parliament and State Legislature has discretion to make laws relating to town and country planning. ${ }^{30}$ The Town and Country Planning Act 1976 will only be applicable in a State when it is adopted in accordance with the prescribed procedure. The State Authority has discretion in deciding when and which part of the Act may come into force in a State or local planning authority area. Thus, it may not be possible to include local planning authorities that have yet to be gazetted as having adopted provisions of the Town and Country Planning Act 1976, providing for the establishment of the Regional Planning Committee. This may pose difficulties in arranging the sharing of powers among the

$27 \quad$ Town and Country Planning Act 1976, s. 3.

28 "Federal List" which is the First List set out in the Ninth Schedule to the Constitution, being the list enumerating the matters with respect to which Parliament may make laws; State List which is the Second List set out in the Ninth Schedule to the Constitution, being the list enumerating the matters with respect to which a State Legislature may make laws, and Concurrent List which is the Third List set out in the Ninth Schedule to the Constitution.

29 Watts, R.L., New Federations: Experiments in the Commonwealth, (Oxford, Clarendon Press, 1966) at p. 13.

$30 \quad$ Federal Constitution of Malaysia 1957. 
local planning authorities that are within a region but have yet to adopt the relevant provision.

The local authority is established at the discretion of the State Authority in consultation with the Minister and Secretary of the Election Commission and such is declared and notified in the Gazette. The declaration specifies the area in the state to be a local authority area, assigns a name to such area, defines the boundaries of the area and determines the status of the local authority as to whether it is a Municipal or District Council. ${ }^{31}$ The local authority is vested with powers to plan and control development activities in its local authority area by virtue of section 6 of the Town and Country Planning Act 1976. The State Authority assumes a vital role in determining or altering the status of any local authority area, and by notification in the State Gazette may, extend the application of the Local Government Act 1976 or any by-laws made thereunder to any non-local authority area. The local authority can only act according to what is expressly or impliedly authorized or permitted by the Local Government Act 1976. Any act of the local authority proven to be not within the ambit of the statute, can be declared to be ultra vires. ${ }^{32}$

The courts have played a role in controlling any perceived transgression of powers by the local authority. A good example is the exercise of powers as the local planning authority. ${ }^{33}$ In Datuk Bandar Kuala Lumpur $v$ Zain Azahari Bin Zainal Abidin, ${ }^{34}$ the respondent had obtained certiorari from the High Court to quash the decision of the local planning authority on the grounds of unreasonable exercise of discretion. The local planning authority had granted planning permission in respect of a disputed development project. Section 22(5) of the Federal

$31 \quad$ Local Government Act 1976 (Act 171) s. 3.

$32 \quad$ Datuk Bandar Kuala Lumpur v Zain Azahari Bin Zainal Abidin [1997] 2 MLJ 17; See also Yian Sdn. Bhd. v Datuk Bandar Kuala Lumpur \& Anor [1999] 3 MLJ 685 where the decision in Datuk Bandar Kuala Lumpur v Zain Azahari Bin Zainal Abidin [1997] 2 MLJ 17 was followed; See Majlis Perbandaran Seberang Perai $v$ Tropiland Sdn. Bhd. [1996] 3 MLJ 94.

33 Under the Town and Country Planning Act 1976, s. 5(1), the local authority shall be the local planning authority for such local authority's area.

$34 \quad$ [1997] 2 MLJ 17. 
Territory (Planning) Act 1982 requires the local planning authority to give written reasons for its decision to grant or refuse planning permission, as the case may be. It was held in this case that the local planning authority had failed to comply with the requirements of the said section when it failed to give written reasons for its decision. ${ }^{35}$ In dismissing the appeal by the local planning authority, the Court of Appeal indicated that:

"[A] public decision-maker...upon whom a power or discretion is vested by Parliament is akin to a trustee. He is under obligation to exercise it reasonably and in accordance with the terms of the relevant statute that confers the power or discretion.”36

In Pengarah Tanah dan Galian Wilayah Persekutuan v Sri Lempah Enterprise Sdn. Bhd., ${ }^{37}$ the Federal Court was faced with the task of setting the limits to the powers vested on the Federal Territory Land Executive Committee to impose conditions upon the approval of an application to vary express conditions on a land title. In holding that the exercise of power by such authority was ultra vires, following a line of English cases decided under the Town and Country Planning Act in the United Kingdom, ${ }^{38}$ the Federal Court observed, inter-alia, that the approving authority does not have uncontrolled discretion to impose whatever condition it likes.

The local planning authority is vested with wide discretionary powers to execute its planning functions effectively, including regulating, controlling and planning development and use of all lands and buildings in its local authority area as well as those assigned by the State Authority or the State Planning Committee. ${ }^{39}$ However, its powers are not absolute

$35 \quad$ See Sharifah Zubaidah Syed Abdul Kader, "Challenging Planning Conditions: Wednesbury Unreasonableness and the Making of Consequential Orders” in [2002] 2 MLJ ccxii.

$36 \quad$ Gopal Sri Ram JCA at p. 30 of the case.

$37 \quad$ Pengarah Tanah dan Galian Wilayah Persekutuan v Sri Lempah Enterprise Sdn. Bhd. [1979] 1 MLJ 135. Pyx Granite Co. Ltd v Ministry of Housing and Local Government [1958] 1 All ER 625 and Fawcett Properties v Buckingham County Council [1960] 3 All ER 503.

39 Town and Country Planning Act 1976, s. 6(1). 
and subject to control by the State Authority ${ }^{40}$ as well as the courts as described above. In respect of any area in a state that does not form part of a local authority area, the State Director for Town and Country Planning will be appointed to be the local planning authority. ${ }^{41}$

Thus, the establishment of a Regional Planning Authority may not be well accepted by local planning authorities for fear of having to surrender their wide powers to a Regional Planning Authority. This is an important issue that needs to be seriously considered. The State Authority and the local planning authorities having used to administering the land use planning and development control process for decades may not be inclined to consent to the creation of a regional planning authority for fear of having to share the existing resources and opportunities within their areas with other local authorities from different states. Prejudices and fear on the part of the local authorities that lack resources of having to be subservient to the affluent local planning authorities is another issue that may promote defiance.

\section{(b) The Legal Powers of the Regional Planning Authority}

Laws, statutes and ordinances are the tools that planners use to help communities bring their common goals to implementation. The regional planning authority that is to be established must be given power to effectively manage the affairs of the region. The present legal framework providing for the establishment of the regional planning authority merely confers consultative powers and no authority whatsoever to the committee. In order for the committee to function effectively, they must be given the authority to implement and enforce proper planning regulation: Merely establishing a regional planning committee with consultative and advisory powers may not be able to achieve the desired results.

The fact that certain matters are effectively handled at local level must not be ignored. The role of the local planning authority is no less important in the circumstances. However, the regional planning authority assumes a broad comprehensive community planning function.

$40 \quad$ Town and Country Planning Act 1976, s. 3.

$41 \quad$ Town and Country Planning Act 1976, s. 5. 
As such it can only function effectively if there is coordination and effective participation between all administrative levels, sectors, general public, NGOs and industries. Furthermore, town and country planning is placed in the Concurrent List, as such it is under the purview of the powers of the State Authority.

The other issue is financing and who is responsible for providing what resources towards the successful establishment of the regional planning authority. Financial matters usually assume an important role in any arrangement involving a number of different authorities.

In Malaysia for instance, division of powers between the federal and state is strongly guarded by the state. The federal government is able to exercise some control by providing funding incentive to the state. Thus, the federal government can consider increasing the existing funding incentives to prompt the state authorities to surrender some powers, especially those related to the sectors that can be improved by coordination between the different local planning authorities such as transport, flood mitigation, traffic control, improving and relocation of squatter areas, providing basic amenities, controlling speculation on costs of land and housing, preventing environmental degradation, and avoiding the dominance of selected ethnic groups in physical space.

\section{LOOKING FOR SUITABLE MODEL FROM OVERSEAS EXPERIENCES}

What is the experience of other municipal regions in the world? Would it be useful to look at the institutional framework in other jurisdictions? A review of institutional models from other jurisdictions seems to point to the hypotheses that institutional models must suit the type of government. This paper looks at Sydney in Australia, Toronto in Canada, London in United Kingdom and Mumbai in India. Sydney and Toronto are in countries with a similar government system as Malaysia while London and Mumbai are in countries with a different system of government. See Table 1 below. 
Table 1: Metropolitan Regions and Type of Government

\begin{tabular}{|l|l|l|}
\hline Metropolitan Region & \multicolumn{1}{|c|}{ Country } & \multicolumn{1}{c|}{ Type of Government } \\
\hline Sydney & Australia & Federal Parliamentary Democracy \\
\hline Toronto & Canada & Federal Parliamentary Democracy \\
\hline London & United Kingdom & Unitary Parliamentary Democracy \\
\hline Mumbai & India & Republic Parliamentary Democracy \\
\hline
\end{tabular}

\section{a. Sydney}

Sydney covers an area of about 12,144.6 square kilometers and has a population of 4.2 million. It is the state capital of New South Wales in Australia. There is no regional level governing body for planning its metropolitan region. All 38 local government areas in Sydney are administered by the state government through the New South Wales Department of Planning. Here, like under the Malaysian planning system, there is strong state involvement in planning decisions. The State Department of Planning prepares the Regional Environmental Plans and the local councils prepare the Local Environmental Plans. The New South Wales government has recently developed a new metropolitan strategy for Sydney and the Sydney Greater Metropolitan Region. This regional strategy however does not change the current institutional set up although we can see that it acts to inform private sector investment, which is part of what is termed as 'immaterial infrastructure' in regional governance. ${ }^{42}$

\section{b. Toronto}

Toronto covers an area of 629.91, square kilometres and has a population of 5.7 million it is the provincial capital of Ontario in Canada. Toronto used to have a regional authority established by statute in the

42 Olsson, ibid. 
name of Municipality of Metro Toronto between 1954 and 1997.43 It however, became irrelevant as it served barely $50 \%$ of the Greater Toronto Area and residents were more concerned about local matters. Presently, the City of Toronto is the governing authority. It was established through the amalgamation of the former Metro Toronto with six member municipalities. The Toronto City Plan is underway and will be good to observe in the future. The planning system in Canada is also very much state controlled. The Ministry of Municipal Affairs and Housing sets out the planning policy and the Ontario Municipal Board is in charge of City Plan approval. The City of Toronto merely drafts the plan. ${ }^{44}$

\section{c. London}

The Greater London Authority ('GLA')was created to improve the coordination between the London boroughs, and the Mayor of London's role is to give London a single person to represent it. The GLA is responsible for co-ordinating land use planning in Greater London. The mayor produces a strategic plan, the "London Plan”. The individual London Borough councils are legally bound to comply with the plan. The mayor has the power to over-ride planning decisions made by the London Boroughs if they are believed to be against the interests of London as a whole. The Mayor proposes policy and the GLA's budget, and makes appointments to the capital's strategic transport body (Transport for London) and economic development body (the London Development Agency). One of the primary purposes of the London Assembly is to hold the Mayor of London to account, and to scrutinise their actions and decisions. The Assembly must also accept or amend the Mayor's budget on an annual basis. ${ }^{45}$

$43 \quad$ Donald N. Rothblatt, "North American Metropolitan Planning Reexamined, Urban and Regional Planning Department,” San Jose State University, Working Paper 99-2.

Accessed via Internet at http://igs.berkeley.edu/publications/ workingpapers/99-2.pdf.

Accessed via Internet at http://www.torontoalliance.ca/ urban_challenges/ on 20 January 2008. 
The plan replaced the previous strategic planning guidance for London issued by the Secretary of State and known as RPG3. It is a requirement of the Greater London Authority (GLA) Act 1999 that the document is produced and that it deals only with matters that are of strategic importance to Greater London. The Act also requires that the London Plan includes in its scope; the health of Londoners, equality of opportunity and contribution to sustainable development in the United Kingdom

The plan is a spatial development strategy for the Greater London area and has six objectives: to accommodate London's growth within its boundaries without encroaching on open spaces; to make London a better city for people to live in; to make London a more prosperous city with strong and diverse economic growth; to promote social inclusion and tackle deprivation and discrimination; to improve London's accessibility and to make London a more attractive, well-designed and green city

\section{d. Mumbai}

Mumbai Metropolitan Regional Development Authority (MMRDA) is an Authority that is responsible for the development of Mumbai Metropolitan Region (MMR) which comprises the Megacity of Mumbai that is the capital of the Maharashtra State in India. The rapid growth led to the establishment of the MMRDA on the 26th January 1975 under the Mumbai Metropolitan Region Development Authority Act, 1974. The Government of Maharashtra is an apex body for planning and co-ordination of development activities in the Region. The goal of achieving a balanced development of the Region is attempted by the MMRDA through the preparation of perspective plans, promotion of alternative growth centres, strengthening of infrastructure facilities and provision of development finance

In order to implement these strategies, the MMRDA prepares plans, formulates policies and programmes and helps in directing investments in the Region. In particular, it conceives, promotes and monitors the key projects for developing new growth centres and brings about improvement in sectors like transport, housing, water supply and environment in the Region. Moreover, if a project is of particular 
significance, the MMRDA takes up the responsibility for its implementation. ${ }^{46}$

The first Regional Plan for the Mumbai Metropolitan Region was sanctioned in 1973. As a part of its statutory responsibility, the MMRDA undertook revision of the Regional Plan taking into account the changes occurring in the population, economy and physical developments in the region. The existing land use survey was carried out using remote sensing techniques. On that basis urban sprawl maps, existing land use maps and urban land use zoning maps for the Region were prepared. The MMRDA also conducted a Multi-purpose Household Survey in the region on sample basis. The survey, which also included houseless and institutional population, provides valuable data on household profiles and living conditions of the people. All the spatial and attribute data were organized under a GIS. Land-use proposals for future growth in the Region were formulated by integrating the results of various studies, and the Draft Regional Plan for 1996-2011 was prepared both in English and Marathi languages. Draft Regional Plan was published on the 15th January, 1996. After following due procedure, the Regional Plan for 199620011 was approved by the Government in September, 1999.

From the above, cursory discussion on Sydney, Toronto, London and Mumbai, it is safe to deduce that metropolitan regional planning depends heavily on the influence of the state government in the institutional framework. A trans-boundary regional authority as is proposed for under section 6A of the Town and Country Planning Act 1976 may face a host of challenges, unseen in the cases of Sydney, Toronto, London and Mumbai where coordination between the different local authorities were forthcoming especially where they are aware of the benefits of regional cooperation.

46 Mumbai Metropolitan Regional Development Authority, Internet Edition at http://www.mmrdamumbai.org/planning_regional.htm Accessed on 15 December 2007. 


\section{SUGGESTIONS TO IMPROVE THE LEGAL AND INSTITUTIONAL FRAMEWORK FOR REGIONAL PLANNING AUTHORITY IN MALAYSIA}

It is not an easy task to overcome the barriers posed by 'homerule' to promote regional cooperation. In Malaysia, the present constitutional arrangement makes it extremely difficult to establish a regional authority that can help promote efficient and effective regional growth since it cannot be given legal powers and sanctions to administer regional matters. The following suggestions are proposed to help overcome the tension between 'home-rule' and establishing of a regional authority in Malaysia.

The following paragraph will suggest some measures that could be used to improve the legal and institutional framework for regional planning authority in Malaysia.

\section{a. Vesting the Regional Planning Authority with Legal Powers}

Any Regional Planning Authority can function effectively to achieve the objectives of a regional plan if it is vested with legal powers and sanctions to promote and ensure compliance on the part of its members. A body without any legal powers to implement law, policy and enforce offences may not be able to effectively achieve the desired results. The various local planning authorities and State Authorities who come under the jurisdiction of the regional planning authority may not be willing to surrender their powers to the regional planning authority. They may continue with their existing development strategies for their respective areas without considering the need to promote development that meets the regional requirements.

The State Authorities in Malaysia having used to be in control or in charge of land use planning and development control activities within their boundaries, may be reluctant to surrender their powers to a new organisation established by the Federal Government. The division of power under the Federal Constitution establishes state autonomy whereby the Federal Government and government of other states cannot interfere with business of a state government. It does not mean however that co- 
operation and co-ordination between the Federal Government and the states, as well as the states themselves is contrary to federalism. ${ }^{47} \mathrm{In}$ fact co-ordination and co-operation between the governments at all levels are very much encouraged. This notion is very clear from the Reid Commission Report:

\begin{abstract}
"When we say that exclusive responsibility should rest with the Federal Government or with the State Government as the case may be we do not intend to hamper or discourage co-operation between the States and the Federation. On the contrary we think that close co-operation between them will promote the interests of all concerned and be of great benefit to the nation." ${ }^{48}$
\end{abstract}

Though there is a clear separation of jurisdiction between the Federal and State Government, it should not be forgotten that the separation can always be waived to promote cooperation between both levels of government to promote effective regional planning. On the contrary, close co-operation between the two governments will be able promote the interests of the nation especially in respect of achieving sustainable development and benefitting the nation.

Furthermore, it should not be forgotten that town planning is a concurrent matter, not a state exclusive matter, which makes the position not contrary to the division of powers under the Federal Constitution. Thus, the Federal government is in the position to establish the Regional Planning Committee to ensure effective coordination of land development activities and management of resources. The Federal Government can also make this possible by providing incentive funding to the States' and convincing them to surrender some of their powers in relation to land use planning and development control to the Regional Planning Authority.

$47 \quad$ Ainul Jaria Maidin and Khairil Azmin Mokhtar, "Usurpation of State Autonomy or Coordinative Federalism?: Constitutional Implications Arising From the Establishment of the National Physical Planning Council on Malaysian Federalism,” [2007] Law Review (Sweet \& Maxwell Asia) pp. 446-461 at p. 460.

48 Reid Commission, The Federation of Malaya Constitutional Commission (Government Printer: Kuala Lumpur, 1957) para 83, page 34-5. 
It is suggested that the Malaysian government study the workings of regional planning authorities in other countries to find a workable model. Regional planning while retaining individual local planning authority power, is a difficult task that has been made more positive with incentive funding in many countries. This means incurring of heavy financial commitments on the part of the Federal Government. The state authorities may be persuaded to surrender some of their powers relating to land use planning and development control to the Regional Planning authority with incentive funding.

\section{b. Using Religious Values and Ethics to Influence State and Local Planning Authorities to Consent to Regional Cooperation}

Resorting to use of religious values and ethics to influence the state and local planning authorities to surrender some of their powers to the Regional Planning Committee is another interesting thought provoking idea that can be studied. The Malaysian administrative authorities at the State government who are predominantly Muslims may be persuaded to surrender some of their powers by using Shariah principles. A Muslim administrator's motivation for work and excellent services are not limited towards achieving of self-fulfilment, upward mobility, improving material gains or service to the nation, but more on realising his position as the Vicegerent (Caliph) and Trustee of God the Almighty. As the Vicegerent he is the holder of the trust or Amanah on the Earth. He is expected to execute his functions along the principles of Shariah which requires the protection of the interest and welfare of the public, rather than material gains. Regional Planning is said to be an important factor in realizing sustainable development as such, the planning authorities must be advised that their work is a form of virtuous deed, which is the key to the attainment of true success in this world and the Hereafter being their final destination. The planner's work is a form of servitude to God and as such he will carry out his administrative tasks without focusing too much on his personal achievement but for the betterment of the nation as a whole.

The responses and priorities should be based on the moral authority of being of service to humanity. The Qur'an provides in Surah Ali Imran (3) verse 104 to the effect that, "Let there be a community among you who call to the good, and enjoin the right and forbid 
the wrong, they are the ones who have success. For Muslims sustainable living is based on the Fitra-the natural paradigm of Allah Ta'ala's creation and adding the spiritual and political to the three pillars of sustainable development would make this a very Islamic concept. ${ }^{49}$ These five pillars in fact define the externalities of the Islamic system and balance out the classical five pillars of individual practise. ${ }^{50}$

Morality and ethics professed by man can play an important role in ensuring effective implementation and enforcement of law and regulation without fear or favour against all stakeholders in the land planning and development control process. ${ }^{51}$ It is also useful in ensuring accountability and transparency amongst the administrators. Law enforcement authorities, that subscribe to religious values and beliefs will at all times hold themselves responsible to uphold the trust imposed on them by the creator of this universe. The role of man as vicegerent of God on this earth gives him the locus standi to represent the natural environment and question any harm caused to it. On the other hand, man who is given the trust to safeguard and protect the environment as vicegerent of God must ensure he executes all his administrative functions cautiously so as not to transgress God's commands and deliver sustainable development. Thus, as an administrator at the local authority level, he may not hesitate to surrender some of his powers to the regional planning authority for purposes of promoting smart growth for the betterment of the people of the region.

49 $\quad$ Fazlun M. Khalid, "Sustainable Development And Environmental Collapse An Islamic Perspective”, paper presented at the World Summit on Sustainable Development parallel event Muslim Convention on Sustainable Development National Awqaf Foundation of South Africa, 1 September 2002, Internet Edition at <http://www.islam.co.za/awqafsa/ SUSTAINABLE\%20DEVELOPMENT\%20AND\%20ENVIRONMENTAL\% 20COLLAPSE.htm> Ibid.

51 See generally, Ainul Jaria Maidin, "Religious and Ethical Values in Promoting Environmental Protection in the Land Use Planning System: Lessons for Asian Countries” Journal of Islamic Law Review, Vol. 2 (2006) pp. 53-84, on the discussion on resorting to use of religious values in promoting environmental protection via the land use planning system. 


\section{CONCLUSION}

The provision of section 6A of the Town and Country Planning Act 1976 merely provides for the establishment of a Regional Planning Committee that has very limited powers and may not be able to help improve regional planning administration. Having a regional planning committee without any legal powers and sanctions can severely paralyse even the most efficient regional development plan. Despite the availability of incentives for cooperating in promoting regional planning to help realise the goals of the National Physical Plan, working together however, requires balance and willingness to sacrifice for the betterment of the region. It is important to reassess past methods in order to make necessary adjustments to achieve improved land use organization. There is a need to establish strong linkages with planning authorities at the state and local levels.

Regional planning can be viewed as a consultation process to obtain consent regarding related issues and subsequently to obtain commitments from the different parties involved for the benefit of the general public. Thus, effective networking, teamwork, effective communication and balancing of powers are essential to promote effective regional plan in the regions in Malaysia. More importantly besides accepting funding incentives from the federal government for cooperating in realising regional planning goals, working together sometimes requires balance or sacrifice for the betterment of the region. The establishment of the regional planning authority seeks to establish a more effective mechanism to deal with the increasing problems and predicament arising from land development and delivery of sustainable development. The mechanism established does not transgress the division of power and does not purport to undermine the local authorities or any one State's autonomy. The underlying philosophy of the amendment is to promote consensus, consultation, co-ordination and co-operation, which forms essential elements of a dynamic and durable federal system without undermining State's autonomy. 